second the attenuation due to the absorption of sound in oxygen is so rapid that it decreases to a millionth of its initial intensity in travelling a distance of $60 \mathrm{~m}$. In an atmosphere of oxygen the consonants of high frequency in speech sounds could scarcely be heard across an ordinary street. The absorption of sound in a room at high frequencies is more influenced by the humidity and temperature of the air than by the absorbing boundaries of the room or the audience. The 'acoustic transparency' of the air at any temperature and humidity can be calculated. A new technique is furnished for investigating not only the nature of molecular collisions but also the nature of the molecular forces involved.

The only foreign delegates present at the meeting were the representatives of the South African Association for the Advancement of Science and the Royal Society of South Africa; they were Prof. H. B. Fantham and Mrs. Fantham (Dr. Annie Porter), of McGill University, Montreal.

The new Committee on Organisation recommended that the Council promote the establishment of local branches, as long since provided for in the constitution. It was voted to encourage the formation of such branches under the direction of the general secretary. On application of a group of seventyfive persons such a branch was established at Lancaster, Pa., and steps taken to assist in the organisation of other places.

By the courtesy of the Mellon Institute, the annual science exhibition occupied an entire floor of the splendid new building of the Institute. The exhibits of the National Bureau of Standards on deuterium and its compounds from twenty-five co-operating laboratories, the Bartol Research Foundation exhibit of cosmic ray apparatus, and the Columbia University demonstration of the production of artificial radioactive substances stood out among a long series of unusual research exhibits for their truly remarkable character.

The addresses of the retiring vice-presidents, given at various times, included the following: Mathematics, Prof. Charles N. Moore of the University of Cincinnati, on "Mathematics and Science"; Physics, Dr. Clinton J. Davisson of the Bell Telephone Laboratories, New York City. on "Electron Optics"; Chemistry, Prof. Arthur B. Lamb of Harvard University, on "Crystallogenetic Adsorbents"; Astronomy. Dr. Vesto M. Slipher of Lowell Observatory, Flagstaff, Ariz., on "The Atmosphere of the Planets as Inferred from Their Spectra"; Geology and Geography, Dr. Rollin T. Chamberlin of the
University of Chicago, on "Certain Aspects of Geologic Classifications and Correlations ; Zoology, Dr. George L. Streeter of the Carnegie Institution, Baltimore, Md., on "The Education of an Anatomist" ; Botany, Dr. Karl M. Wiegand of Cornell University, on "A Taxonomist's Experience with Hybrids in the Wild" ; Anthropology, Dr. T. Wingate Todd of Western Reserve University, on "Anthropology and Growth"; Psychology, Dr. Walter R. Miles of Yale University, on "Training, Practice and Mental Longevity"; Education, Prof. Walter F. Dearborn of Harvard University, on "The Mental and Physical Growth of Public School Children"; Social and Economic Sciences, Prof. Wesley C. Mitchell of Columbia University, on "The Social Sciences and National Planning"; Engineering, Dr. Charles F. Kettering of the General Motors Corporation, Detroit, Mich., on "Some Future Problems of Science and Engineering"; Medical Sciences, Dr. Cyrus C. Sturgis of the University of Michigan, on "Review of Some of the More Recent Advances in the Study of Blood Diseases"; Agriculture, Dr. Albert R. Mann of Cornell University, on "The Agricultural Significance of State and National Planning".

The following officers were among those elected for the year 1935 : President, Prof. Karl T. Compton of Massachusetts Institute of Technology ; General Secretary, Prof. Otis W. Caldwell of Teachers College, Columbia University; Vice Presidents of the Sections : Prof. T. H. Hildebrandt of the University of Michigan (Mathematics); Dr. John T. Tate of the University of Minnesota (Physics); Prof. Moses Gomberg of the University of Michigan (Chemistry); Dr. H. R. Morgan of the U.S. Naval Observatory (Astronomy); Prof. Walter E. McCourt of Washington University (Geology and Geography); Dr. Oscar Riddle of the Station for Experimental Evolution, Cold Spring Harbor, N.Y. (Zoological Sciences); Prof. E. W. Sinnott of Columbia University (Botanical Sciences) ; N. C. Nelson of the American Museum of Natural History, New York City (Anthropology) ; Joseph Peterson of George Peabody College for Teachers, Nashville (Psychology); Shelby Harrison of Russell Sage Foundation, New York City (Social and Economic Sciences); Dr. George Sarton of Harvard University Library (Historical and Philological Sciences); H. N. Davis of Stevens Institute of Technology, Hoboken, N.J. (Engineering) ; Stanhope Bayne-Jones of Yale University Medica] School (Medical Sciences); H. K. Hayes of the University of Minnesota (Agriculture); Prof. F. B. Knight of the University of Iowa (Education).

HENRY B. WARD.

\title{
Science and the Newspaper Press in the United States
}

\footnotetext{
$\mathrm{O}$ $\mathrm{NE}$ of the leading features of the recent meeting of the American Association for the Advancement of Science held at Pittsburgh, Pennsylvania, was a symposium on the relation between science and the Press. Although within the past decade Press reports of scientific work have become far more satisfactory than formerly, and distrustfulness of the Press on the part of scientific men has been greatly reduced, certain difficulties still exist. The object of the symposium was to bring these difficulties frankly into the open, in the hope that recognition and subsequent discussion might lead to their eventual removal.
}

The speakers at this symposium were: Dr. Karl T. Compton, president of the Massachusetts Institute of Technology, who is president-elect of the American Association; Mr. David Dietz, science editor of the Scripps-Howard Newspapers, and president of the National Association of Science Writers, Cleveland, Ohio ; Mr. Robert D. Potter, Science Service, Washington, District of Columbia, speaking for the director, Mr. Watson Davis ; Dr. Edward R. Weidlein, director of the Mellon Institute for Industrial Research, Pittsburgh, Pennsylvania; Mr. William L. Laurence, science news editor, the New York Times, New York ; Dr. Benjamin C. Gruenberg, 
American Association for Adult Education, New York; Mr. Gobind Behari Lal, science editor, Hearst Newspapers, New York; Mr. Thomas R. Henry, staff correspondent, the Washington Star, Washington; and Mr. Howard W. Blakeslee, science editor, the Associated Press, Now York. It is expected that the contributions of these writers and others will be published in a forthcoming number of Science.

It was gratifying to note the interest taken in this symposium by the members of the Association, and to observe the co-operative spirit-indeed, the cordial relationship-that now exists between the scientific men and the representatives of the Press. For it is only within the past few years that science and the Press have come really to understand and to appreciate each other.

The present system of reporting science in the Press of the United States may be said to have had its inception in 1921. In that year, the late $\mathrm{Mr}$. Edward Willis Scripps established the organisation known as 'Science Service', which had as its object making "the greatest use of the press in the way of disseminating the knowledge which is the result of painstaking research carried on by a few hundred, or at least a few thousand, well trained men with great mental capacity". In the same year the Scripps-Howard newspapers appointed Mr. David Dietz as science editor, and Mr. Alva Johnston was selected to write the articles on science for the New York Times.

The Boston meeting of the Association in 1922 was reported to the Press by Science Service, Mr. Dietz and Mr. Johnston. For his work in reporting this meeting Mr. Johnston was awarded the Pulitzer prize of one thousand dollars for "the best job of reporting done during the year". The award naturally attracted attention to science writing, and within the next few years several other newspapers, among them the Washington Star, the New York Herald. Tribune and the Detroit News, designated young men of outstanding ability as scientific writers for them.

In 1927 the Associated Press, a co-operative Press association fumishing news to about 1,300 newspapers, appointed two of its ablest young men as science editors, whose duty it was to write science exclusively for the member newspapers. In selecting the men for these positions, Mr. Kent Cooper, the general manager, adopted the principle that the best results in writing science for the Press are to be obtained by men who are, primarily, trained journalists of exceptional ability. This principle has proved to be sound, and has been generally followed by the Press in the United States.

In April 1934 there was organised the National Association of Science Writers, with the membership limited to staff members of newspapers and press associations who devote their major efforts to science. The purpose of this Association is "to foster the dissemination of accurate scientific knowledge by the press of the Nation, in cooperation with scientific organisations and individual scientists". The charter members were twelve in number, representing the Associated Press (2), Science Service (2), the ScrippsHoward Newspapers, the Philadelphia Inquirer, the Washington Star, the New York Times (2), the Hearst Newspapers, the New York Herald-Tribune and the Detroit News. One honorary member was elected. Mr. David Dietz, science editor of the ScrippsHoward Newspapers, who is a fellow of the Royal
Astronomical Society and has attended and reported meetings of the British Association, was elected president.

The growth of interest in science on the part of the Press of the United States is well shown by the fact that at the recent Pittsburgh meeting of the Association there were sixteen science writers from other cities, ten of them members of the National Association of Science Writers. At the meeting in Boston in the preceding year there were ten from other cities. At the Boston meeting in 1922 there had been only four.

Appreciation of the excellent work the science writers connected with the daily Press are doing is being shown in many different ways. As examples it may be mentioned that during the past year the commencement oration at the Massachusetts Institute of Technology, at Cambridge, Massachusetts, was delivered by Mr. Howard W. Blakeslee, science editor of the Associated Press, and the commencement oration at the Carnegie Institute of Technology, at Pittsburgh, Pennsylvania, was given by Mr. Waldemar Kaempffert, science editor of the New York Times. Also, Mr. Thomas R. Henry, science writer for the Washington Star, was elected a member of the Washington Academy of Sciences as an appreciation of his work, and shortly thereafter addressed the Academy on the relation between science and the newspapers.

In the United States, the newspapers have now become an important element in the scientific complex of the country. They are by far the most important intermediary between those who are engaged in scientific work and the public at large. As such, they are the most important factor, so far as science is concerned, in what is commonly called adult education. It is a pleasure to be able to state that they appreciate their responsibilities and are doing everything in their power, at no small expense to themselves, for the common good.

\section{University and Educational Intelligence}

Birmingham.-The Huxley Lecture is to be delivered on March 14 at 5.30 p.m. in the medical theatre by Sir Thomas Lewis, who has chosen for his subject "Clinical Science within the University".

Cambridge.-Prof. Othenio Abel, recently appointed professor of geology and palæontology in the University of Göttingen, will give three lectures on palæobiology and evolution in the Department of Zoology at 5 p.m. on February 11, 13 and 15.

The Faculty Board of Archæology and Anthro. pology has appointed T. T. Paterson, of Trinity College, and J. R. B. Stewart, of Trinity Hall, to Anthony Wilkin studentships.

London.- The County Borough Council of Croydon is making a grant of $£ 10,000$, payable over ten years, towards the erection of new buildings in Bloomsbury, and the Westminster Bank has granted $£ 500$ for the same purpose.

OxFORD.-The scientific work of early members of Oriel College was the subject of a public lecture by Dr. Gunther on February 2. The benefactions to the library and list of graduates show that medical studies flourished there at the end of the sixteenth 